\title{
Evaluation of Alexandria Police Hospital Gardens Environment : Utilization and Garden Users Satisfaction
}

\author{
M.G.EL-Torky', Thanaa.M.Ezz ${ }^{2}$, Hend M. A. Elsweefy ${ }^{3}$ \\ 1. Floriculture, Ornamental Horticulture and Landscape Gardening Department, Faculty \\ of Agriculture, Alex. Univ. \\ 2. Plant Production Department, Faculty of Agriculture Saba Basha, Alex. Univ. \\ 3. Landscape gardening engineer in Alexandria Police Hospital
}

Corresponding author: Hend M. A. Elsweefy, e-mail: hendelsweefy@yahoo.com

\begin{abstract}
Alexandria Police Hospital (APH), Alexandria, Egypt was planned and built between 2005 and 2010. It was established exactly in the entrance of Alexandria city on CairoAlexandria desert road occupying an area of about $42000 \mathrm{~m}^{2}$. The hospital has a garden of about $18 \%$ of the total area. Since the concept of healing garden is not yet mature in Egypt, an evaluation was conducted between 2010 and 2014 to determine whether the garden was matching the international standards of hospital or healing gardens and whether the garden was meeting the goals and benefits of similar healing gardens. Results from site observations and the statistically analyzed questionnaires indicated several facts: the majority of the tested sample believe that the hospital garden is a very important component of the healthcare facilities. With respect to the general features and components of the gardens, the questionnaires proved that there were points of satisfaction; included the general shape and appearance of the gardens, the general shape of plants and green lawns, garden maintenance and cleaning level which gives a nice pleasant welcome shape to the garden as well as creates a healthy atmosphere for patients and other garden user groups. On the other hand, there were serious points of dissatisfaction including the absence of pergolas, umbrellas and trellises which have been reflected as a problem since there is no way to protect patients and visitors from wind, sunrays or extremes in temperature. Most of the visitors were dissatisfied about the limited variety of plant species and colures, the plants of the garden are not enough to expertise the patients five senses, seeing, smelling, tasting, touching or hearing. The garden users complain, also, because there are no enough walkways with standard characteristics with normal slope for moving wheelchairs. The absence of sitting places in the garden as well as the absence of sculpture and other artistic pieces was one of the serious complains of the garden users. Finally, most of the visitors expressed their dissatisfaction concerning the night lighting of the garden which proved to be insufficient which makes a problem especially for old patients, visually impaired individuals as well as those who have undergone leg bones operations. Based on the results obtained, recommendation for changes was developed to promote better use and benefits of the garden. These research findings can be used to guide the future planning, design, building and subsequent evaluation of garden environments in healthcare facilities.
\end{abstract}

Key words: Healing Gardens, Hospital gardens, Alexandria Police Hospital (APH)

\section{INTRODUCTION}

Hospitals are healthcare institutions which provide patient treatment with specialized staff and equipment. Historically, hospitals were often founded and funded by religious orders or charitable individuals and leaders (Hall, 2008). The earliest documented institutions which provided cures were the ancient Egyptian temples followed by the ancient Greece temples which were both dedicated to the healer-Gods (Miller, 2006).

Throughout the history of mankind, contact with nature proved to be beneficial for health and well-being in the different human cultures. Contact with nature proved to be valuable for patients troubled in body, mind, or spirit. During 
the $20^{\text {th }}$ century, the relationship between healing and nature has suffered to a great extent since technology occupied the greater part in the medical community (Horsburgh, 1995 and Ulrich, 1992).

"Hospital Garden" is a common terminology which refers to the gardens which surrounds the buildings of a hospital for beatification and ornamental view. The terminology, however, expanded to cover also some benefits for patients, nurses, doctors, administrative staff members of the hospital in addition to the visitors. Then, the term "Healing Garden" or "Therapeutic" Garden appeared to be more expressive than "Hospital Garden" since both terms cover the beneficial basis of design, curing acceleration. Sometimes the term "Restorative Garden" or "Rehabilitation Garden" is used which include the principle of restoring the balance of the different life dimensions (CooperMarcus and Barnes, 1995 and Annerstedt and Wahrborg, 2011).

The concept of gardens is believed to date back to ten thousand years ago. Gardens of ancient Egypt represent the earliest beginning of gardens and garden design (Berall, 1978). During that time very little was known about physical illness, and the common belief was that healing would come through exposure to nature and through connection with God. Ancient Egyptians adopted this concept in old temples (Janick, 2002), Japanese and Chinese cultures followed (Jiang, 2014). The first healing gardens in the western world date back to the Middle Ages in Europe (Cooper-Marcus and Barnes, 1999). But, unfortunately, the hospital gardens during much of the $20^{\text {th }}$ century were either mostly removed or forgotten, they were replaced by high-tech machines, increased specialization, and new pharmaceuticals (Cooper-Marcus and Barnes, 1999). But suddenly and surprisingly, a return to nature in medical settings began to occur again in the 1990s. A considerable amount of research supported again the theory that views of, or access to, nature had positive effects on health outcomes (Cooper- Marcus, 2005).

Well- designed hospital gardens not only provide calming and pleasant nature views, but can also reduce stress and improve clinical outcomes through other mechanisms, for example, fostering access to social support and privacy, and providing opportunities for escape from stressful clinical settings (Ulrich, 1999). When designing a healing garden, the focus should be on the people who are supposed to use the garden, or what is called the users group (Stigdotter and Grahn, 2003). Shahrad (2012) mentioned the importance of seven principles which should be considered when designing a healing garden: feeling of security, understanding user groups and their needs, offering different types of activities, having different rooms or spaces, having the basic characteristics for rest and activity, achieving both privacy and social interaction, and the importance of surrounding views.

Different hardscape components of hospital gardens should be carefully considered. Transition from inside to outside should be safe and easy for patients and other garden users (York, 2009). Providing suitable walkways that are firm, stable and slip resistant is of priority especially for those using assistive mobility equipment or even blind patient (National Center on Accessibility, 2009). Walkways should have running slope no greater than $5 \%$ and cross 
slope no greater than 2\% (United States Access Board, 1998). The width of the walkways should be a minimum of 36 inches. Outdoor lighting is important hardscape element since it can assist in the safety and security of patients and other users. A combination of outdoor lighting fixtures will enhance night time visibility and safety (York, 2009) and maximize the therapeutic benefit by allowing patients to use the gardens safely after dark, or even to have a look out to the garden from indoors (Cooper- Marcus and Barnes, 1995). Sitting and resting places are also important for the comfort and safety of users, design of seating elements should assist those with coordination, mobility, balance, and strength limitations (United States Access Board, 2007). The design of healing gardens must create a comfortable outdoor microclimate to protect garden users from winds and extremes in temperature, the use of pergolas, trellises and umbrellas becomes of great importance (Young, 2001 and Carstens, 1998). Even sculpture and other artistic pieces may become a factor of recovery when carefully used (Minter, 1995; Sagar, 2006, Wieland, 2007).

On the other hand, the presence of ornamental plants is the key element of a positive healing environment (Cooper- Marcus and Barnes, 1995 and Paine et al., 1998). Plants creat pleasure and can bring healing through the five human senses, either physically or more indirectly via memories and mood (Minter, 1995). This depends on the so called "man's perception of the landscape". To perceive one's environment is to become aware of it through the senses of seeing, hearing, touching, smelling, and tasting (Carpenter et al., 1975). For excellent review about using the five human senses to enjoy and benefit the garden see (Minter, 1995).

\section{MATERIALS AND METHODS}

A sample of 218 visitors was selected at random, they received the questionnaire, with the help of the researcher of this thesis, they answered the questions, the results were analyzed by Chi- 2 test. The selected visitors chosen for this part were 115 females and 103 males. Most of them where nurses and administrative employees (38.1\%), while patients were $28 \%$, visitors were $13.8 \%$, and doctors were $20.2 \%$. Meetings, interviews and discussions were made with the different user groups of the selected sample. Several visits, were, also, made to observe the situation of the hospital and garden components, as well.

\section{RESULTS AND DISCUSSION}

\section{* Distribution of the studied cases according to their personal data}

A sample of 218 persons was selected at random and received the questionnaire, with the help of the researchers of this article, they answered the questions. The results were analyzed by $\mathrm{chi}^{2}$ test. About $47 \%$ of the selected persons for questionnaire were males while about $53 \%$ of the samples were females. (Table 1)

Administration people and nurses present the highest percentage of the sample $(38.1 \%)$, followed by patients $(28.0 \%)$, then doctors $(20.2 \%)$ while visitors presented the lowest percentage of users (13.8\%). 
Most members of the studied sample visit the hospital on a daily basis (about $64.2 \%$ ), and about $28.4 \%$ visit the hospital on a regular basis while only $7.3 \%$ of the studied sample visit the place irregularly.

About $64 \%$ of the studied sample had higher education level, while $28 \%$ had medium education, only $7 \%$ of the studied sample were non-educated.Most of the selected visitors (68.3\%) showed that they are keen to watch the hospital garden, $13.8 \%$ said they are very keen to watch the garden which they believed to be of a top priority for them. Unfortunately, about $18 \%$ saidthey are not concerned with the garden of the hospital.

From the above mentioned results published in Table (1), it might be concluded that the selected sample of the questionnaire has been recruited at random to present the different categories of users: Patients, doctors, administration employees, nurses as well as visitors, as recommended by Cooper-Marcus and Barnes (1995). More than $80 \%$ of the tested sample said that the hospital garden is very important component of the healthcare facilities, they are keen to watch or to feel the touch of nature provided by the hospital gardens. These preliminary results indicated that the primary function of the hospital outdoor garden space is the creation of calming environment which represents an additional healthcare amenity that provides therapeutic benefits and positive health outcomes (Neducinet al., 2010).

Table (1): Distribution of the studied cases according to their personal data

\begin{tabular}{lcc}
\hline & No & $\%$ \\
\hline Sex & & \\
$\quad$ Male & 103 & 47.2 \\
$\quad$ Female & 115 & 52.8 \\
\hline Reason of visiting & \\
\hline Doctors & 44 & 20.2 \\
$\quad$ Nurses and administration employees & 83 & 38.1 \\
$\quad$ Visitors & 30 & 13.8 \\
Patients & 61 & 28.0 \\
\hline The frequency level of visiting & \\
\hline Daily & 170 & 64.2 \\
Regularly & 62 & 28.4 \\
$\quad$ Non regularly & 16 & 7.3 \\
\hline Education level & 16 & \\
\hline Non educated & 62 & 28.4 \\
$\quad$ Medium education & 140 & 64.2 \\
$\quad$ High education & 39 & \\
\hline Are you keen to watch the hospital garden? & 17.9 \\
\hline No & 149 & 68.3 \\
$\quad$ Yes & 30 & 13.8 \\
$\quad$ Very keen &
\end{tabular}




\section{Distribution of the studied cases according to sufficiency and general satisfaction towards the hospital gardens}

With respect to how sufficient are the gardens of the hospital (with regard to fulfill their wishes) as well the general satisfaction of users towards the hospital gardens, data presented in Tables 2 and 3 clarified the fact that the majority of the studied cases believed that the gardens of Alexandria Police Hospital are quite sufficient $(59.2 \%$ high sufficiency level and $37.6 \%$ moderate sufficiency), while only $3.2 \%$ of the tested sample believed that the gardens of this hospital are not sufficient. On the other hand, $64.2 \%$ of the tested sample were highly satisfied about the gardens whereas $30.3 \%$ were moderately satisfied. Only $5.5 \%$ were not satisfied about the general situation of the gardens of the police hospital.

It was found that patients followed by visitors then nurses and administrators $(67.2 \%, 60 \%$ and $59 \%$; respectively) believed that the garden of the hospital have highly fulfilled their needs. Doctors, due to their limited time among plants occupied the last group of users $(47.7 \%)$ who can feel high degree of sufficiency since they spend most of their time inside the buildings and rooms of the hospital. This explained why $50 \%$ of the doctors have expressed moderate degree of sufficiency with respect to the gardens of the hospital, compared to other users.

With respect to the degree of satisfaction (Table 3), it was found that visitors occupied the highest-level of satisfaction among other garden users (73.3\%) since they enjoy being or passing through the garden compared to all other classes of users whomay be tired enough due to disease and therapy (patients; $57.4 \%$ ) or may be doctors or nurses or administrators who are working hard in the hospital (65.9\% and 65.1\%).

These results agree with the general approach of Kaplan and Kaplan (1989), Tyson (1998) and Cooper-Marcus and Barnes (1995) who have reported that the hospital gardens are necessary for healing to begin: being away, extent, fascination and compatibility. Theneeds of other groups of individuals using the garden; the visitors, the patient's families, the employees (doctors, nurses, administrative workers) must also be considered and respected.

Table (2): Distribution of the studied cases according to sufficiency and satisfaction

\begin{tabular}{|c|c|c|}
\hline & No & $\%$ \\
\hline \multicolumn{3}{|c|}{ The degree of sufficiency } \\
\hline $\operatorname{High}(\mathrm{A})$ & 129 & 59.2 \\
\hline Moderate (B) & 82 & 37.6 \\
\hline Low (C) & 7 & 3.2 \\
\hline Min. - Max. & \multirow{2}{*}{\multicolumn{2}{|c|}{$\begin{array}{c}15.0-46.0 \\
35.12 \pm 6.22\end{array}$}} \\
\hline Mean \pm SD & & \\
\hline Median & \multicolumn{2}{|c|}{36.0} \\
\hline \multicolumn{3}{|c|}{ The degree of satisfaction } \\
\hline $\operatorname{High}(\mathrm{A})$ & 140 & 64.2 \\
\hline Moderate (B) & 66 & 30.3 \\
\hline Low $(\mathrm{C})$ & 12 & 5.5 \\
\hline Min. - Max. & \multirow{2}{*}{\multicolumn{2}{|c|}{$\begin{array}{l}23.0-48.0 \\
39.43 \pm 5.0\end{array}$}} \\
\hline Mean $\pm S D$ & & \\
\hline Median & \multicolumn{2}{|c|}{40.0} \\
\hline
\end{tabular}


Table (3): Opinion of the different classes of visitors towards the garden sufficiency and general satisfaction.

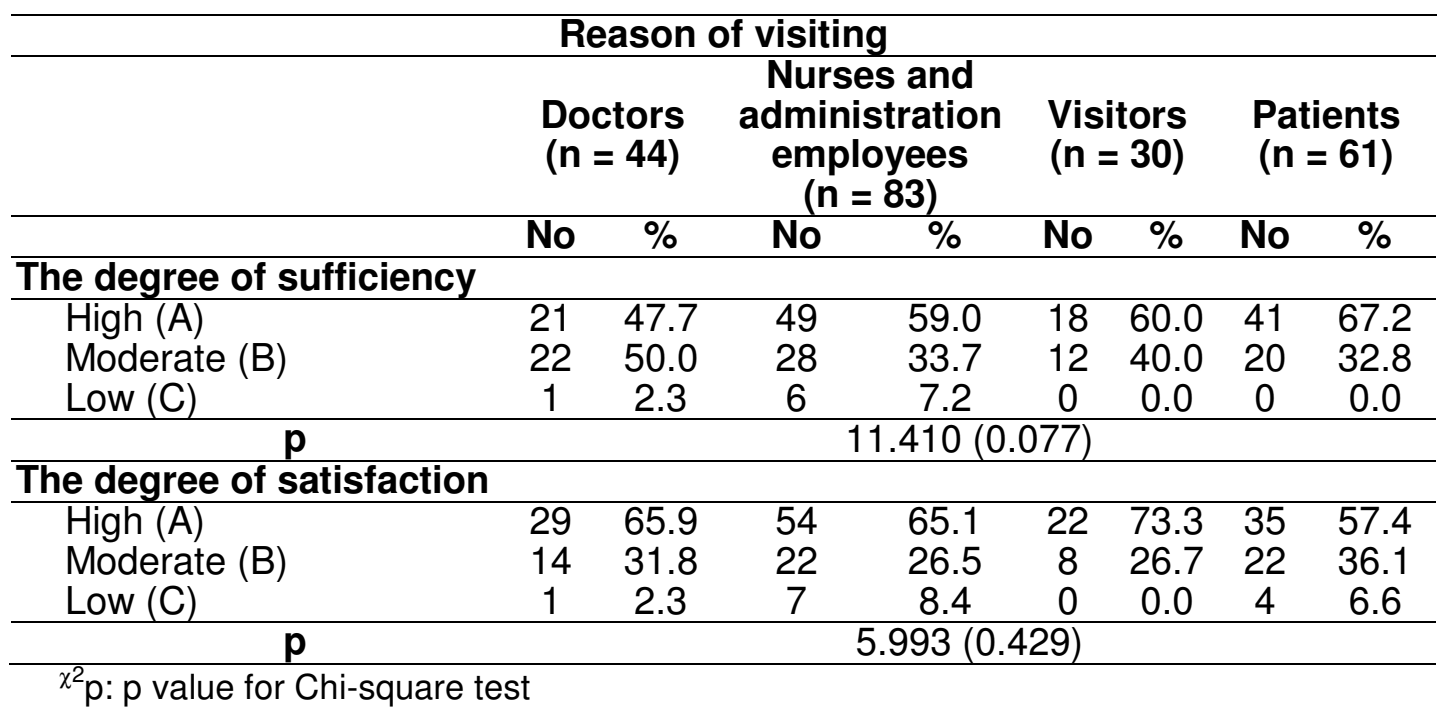

\section{- Opinion of the studied sample about the general features and components of Alexandria Police Hospital gardens:}

With respect to the gardens themselves,thegeneral shape and the different components, which expressed the opinion of the tested sample, results are presented in Table (4). They were classified into two groups for better understanding and better interpretation; points of satisfaction and points of dissatisfaction:

\section{The first group: Points of satisfaction:}

Most of the garden users were happy about the general shape and appearance of the gardens, which is considered an important milestone for the success of any hospital garden as a place for healing or stress reduction (Cooper-Marcus and Barnes, 1995).

Most of the garden users are satisfied with the general shape of plants in the garden, the shape of green lawns, the area of green lawns as well as the amount of flowers in the garden

As a matter of fact, if most of the hospital garden users are satisfied with the general shape of plants in the garden including the green lawns, it might be then a good sign. The presence of good collection of ornamental plants and flowers in the hospital garden is considered to be the key element of a positive healing environment. Exposure to nature has a significant beneficial effect on the emotional state of human beings (Paine et al., 1998). Young (2001), also, supported these results, he reported that plants are the focus of gardens. Planting decisions can determine whether the site is a welcome area that is successfully utilized or not. 
On the other hand, green lawns or even green colour create a feeling of space. They are useful in the treatment of nervous conditions, theyengender a feeling of peace and sanctuary from the outside world (Minter, 1995 and Stewart 2003).

The majority of visitors were greatly satisfied with the garden maintenance as well as the cleaning level of the garden outdoor area. It is considered a good point and positive management for the authorities of AlexandriaPolice Hospitalsince they contracted special companies for either garden maintenance, or general cleaning for the outdoor area. This gives a nice and pleasant welcome shape to the garden as well as creates a healthy atmosphere for the patients and other garden users. Young (2001) explained the importance of the presence of a maintenance program for the garden as well as the whole outdoor area including plants (planting, pruning, replacement, feeding, irrigation, etc.), walkways (cleaning, paving, replacement of damaged areas, etc.).benches, water fountains and all built structures should be thoroughly inspected to minimize the risk of injury to all user groups.

The majority of garden users believe that the place has enough entrances and exits that connect the garden to other different buildings and outdoor areas. Access to outdoor spaces begins with the coordination between the interior and exterior. Exits should be available everywhere to help patients and other garden users to move safely and freely from inside to outside and vice versa. A lighted and covered entry exit can provide shelter from the elements and be more inviting in making the transition to the outside garden area (York, 2009). On the other hand, users of hospital outdoor areas need to find easily their way from inside to outside, the presence of enough number of clear exits makes it easier to move freely from part to another (Miller and Lewis, 1999).

\section{The second group: Points of dissatisfaction:}

Most of the garden users are not satisfied with the shade facilities of the garden; shade resulting from trees is not yet enough due to the comparatively small canopy of the newly planted trees, in addition to the absence of pergolas, gazebos, umbrellas and trellises. Of course, the non-availability of shade facilities in the outdoor garden areas of the Police Hospital is considered to be a weak point in the design, since users of the hospital gardens are more likely to be sensitive to outdoor climatic conditions. The design of healing gardens must create a comfortable outdoor microclimate, to prolong the season and protect users from wind, sunrays as well as extremes in temperature (Young, 2001). Umbrellas, pergolas or gazebos are very important components of hospital gardens since they can create a transitional area between bright and dark areas, to give eyes time to adjust properly as reported by Carstens (1998) and Harris and Dines, (1998).

Most of the tested sample of garden users complains because there are a limited variety of plant colours in the garden. On the other hand, the majority of users groups expressed their dissatisfaction due to the insufficient collection of 
plants of the gardens of Alexandria Police Hospital. It is again a great problem of garden design confronting the administrative staff of this hospital, since the available plants of the garden do not sufficiently help the patients in the process of awakening their human senses. The number of fragrant plant species is so limited for smelling. There are no edible plants to be tasted. The plant variety does not help at all to expertise touching or even moving by wind to encourage hearing sense (Minter, 1995). On top of all, the limited variety of plant or flower colour in the garden. The importance of colour in the healing process has been well known since ancient Greeks and ancient Egyptians. Each colour has a specific meaning and therapeutic effects. The limited variety of plant colours in the garden has definitely a bad effect on the psychology of patients and other users of the hospital garden (Minter, 1995 and Stewart, 2003). The joy of colour in the garden needs skill to contrive successfully, especially as it involves designing with the fourth dimension, time, it can affect mood beneficially and therapeutically as well (Minter, 1995).

Unfortunately, the majority of garden users complain because there are not enough walkways which connect the garden to the different gates of the hospital buildings. Some people mentioned that there is no smooth way with normal slope even for the moving wheelchairs of patients. In the same context, the majority of the tested sample believe that the walkways of the garden are not suitable for wheelchairs, pavement and slope complicated the problem. They believe strongly that the Police Hospital gardens are not suitable for blinds to move freely during day or night.

It is really a serious complain which should be considered by the hospital authorities, walkways are not enough and sometimes do not connect different outdoor spaces together, the biggest problem, the walkways connecting indoor to outdoor are not sufficient or smooth for easy and safe movement of patients, wheelchairs or moving beds and other hospital facilities between the different buildings of the hospital. Providing walkways that are firm, stable and slip resistant can facilitate negotiating the outdoor space especially for those using assistive mobility equipment or people with impaired balance or coordination. The edges of the pathway should be flush with the surrounding grade to accommodate use of a wheelchair, scooter or crutches on the path. Unitary surfaces such as asphalt and concrete, are considered accessible surfaces (National Center on Accessibility, 2009).

Walkways should also have running slope no greater that $5 \%$ and cross slope no greater that $2 \%$ in order to reduce the risk of falls as well as to provide enough slope for drainage (Tranter et al., 1991; Kirchner et al., 2008; and Brawley, 2007). The width of the walkways should be a minimum of 36 inches, which would permit one-way traffic for wheelchair or walker users. Paths at 5 feet allow side-by-side walking, passing of two persons and are wide enough for a wheelchair to make a 180 degree turn (Brawley, 2007).

Most of the garden users complain because of the absence of comfortable sitting places in the garden as well as the absence of all kinds of 
sculpture and other artistic pieces including fountains and bird shelters. While other people believe that portable chairs may be a good substitute for permanent sitting chairs.

The absolute importance of sitting and resting places as well as sculpture and other artistic pieces are reviewed by many researchers. The more opportunities that are provided for persons to sit and rest, the more appealing traveling within an outdoor space may be. Seating should be provided along walking paths, within garden areas, at places to observe nature elements (watching trees, birds, flowers, etc.), and in common areas in order to socialize and visit with family and friends. The size and design of seating elements should assist those with coordination, mobility, balance, and strength limitations (United States Access Board, 2007).Full description of seating places and dimensions as well as benefits are shown by Cooper-Marcus and Barnes (1995).

On the other hand, the use of sculptures, rocks, pieces of wood as well as other artistic pieces might be of some benefit to recovery. Although art may be considered as a psychological component of the auto-immune system that leads to the heling process, but the use of carefully selected art pieces should also be considered (Wieland, 2007 and Sagar, 2006). Statues, on the other hand are considered as stimuli and may hamper patients recovery and create stress (Ulrich, 2000).

Most of the garden users were not happy with the night lighting system of the garden, the number and distribution of landscape lighting in the garden proved to be weak in spite of the importance of lighting such gardens at night. It is will- known that good lighting can help to prevent falls and assist those who are visually impaired detect boundaries (York, 2009). Cooper-Marcus and Barnes (1995) suggested that the night time lighting maximizes the therapeutic benefit by allowing patients and other garden users to use the space safely after dark, or to look out at the garden from indoors.

Table (4): Opinion of the studied sample about the general features and components of Alexandria Police Hospital garden, Alexandria, Egypt.

\begin{tabular}{|c|c|c|c|c|c|c|c|c|c|}
\hline \multirow{2}{*}{ Garden general features and components } & \multicolumn{2}{|c|}{ Disagree } & \multicolumn{2}{|c|}{ Moderate } & \multicolumn{2}{|c|}{ Agree } & \multirow{2}{*}{ Mean } & \multirow{2}{*}{ SD } & \multirow{2}{*}{$\square^{\square}$} \\
\hline & No & $\%$ & No & $\%$ & No & $\%$ & & & \\
\hline General shape of the garden & 6 & 2.8 & 52 & 23.9 & 160 & 73.4 & 2.7 & 0.51 & 172.0 \\
\hline The shape of garden plants & 15 & 6.9 & 84 & 38.5 & 119 & 54.6 & 2.48 & 0.62 & 77.073 \\
\hline The shape of green lawns & 12 & 5.5 & 69 & 31.7 & 137 & 62.8 & 2.57 & 0.69 & 107.789 \\
\hline The area of the green lawns & 18 & 8.3 & 64 & 29.4 & 136 & 62.4 & 2.54 & 0.64 & 97.358 \\
\hline ount of flowers in the garden & 51 & 23.4 & 98 & 45.0 & 69 & 31.7 & 2.08 & 0.74 & 15.477 \\
\hline Gard & 33 & 15.1 & 81 & 37.2 & 104 & 47.7 & 2.33 & 0.72 & 36.119 \\
\hline $\mathrm{Cle}$ & 15 & 6.9 & 84 & 38.5 & 119 & 54.6 & 2.48 & 0.62 & $77.073^{\pi}$ \\
\hline in the garden & 20 & 9.2 & 73 & 33.5 & 125 & 57.3 & 2.48 & 0.66 & $75.862^{\star}$ \\
\hline rden & 149 & 68.3 & 59 & 27.1 & 10 & 4.6 & 3.0 & 2.64 & $136.798^{*}$ \\
\hline The & 105 & 48.2 & 86 & 39.4 & 27 & 12.4 & 2.36 & 0.69 & $45.532^{\pi}$ \\
\hline , tasting an & 78 & 35.8 & 76 & 34.9 & 64 & 29.4 & 2.06 & 0.81 & 1.578 \\
\hline walkways & 102 & 46.8 & 84 & 38.5 & 32 & 14.7 & 2.32 & 0.72 & $36.367^{\wedge}$ \\
\hline ility for wheelchairs & 103 & 47.2 & 73 & 33.5 & 42 & 19.3 & 2.28 & 0.77 & 25.606 \\
\hline Sufficiency of sitting places and sculptu & 130 & 59.6 & 44 & 20.2 & 44 & 20.2 & 1.61 & 0.80 & $67.853^{\wedge}$ \\
\hline Night lighting of the garden & 86 & 39.4 & 76 & 34.9 & 56 & 25.7 & 2.14 & 0.89 & 6.422 \\
\hline
\end{tabular}




\section{Opinion of the tested sample about the importance of hospital gardens}

The awareness level of the people concerning the importance of hospital gardens was also addressed, the results are presented in Table (5) and could be presented as the following:

* The majority of the tested sample agree that the gardens have a great psychological impact on the hospital's users (56.4\% strongly agree+ $36.7 \%$ agree).

* The majority of visitors disagree that most Egyptians believed that the expansion of building sections of the hospital is more important than the creation of green spaces ( $28.9 \%$ strongly disagree $+27.5 \%$ disagree).

* The majority of the tested sample disagree that the hospital gardens lead to transmission of infection because of the spread of insects $(44.5 \%$ strongly disagree $+40.8 \%$ disagree) .

* The majority of people disagree completely that the case of patients will not be affected by their prior experience and interest in gardening $(47.7 \%$ strongly disagree $+38.1 \%$ disagree)

* With respect to the dilemma of spending money on the treatment of patients compared to spending money on the maintenance of the garden, most of the tested sample were not happy about presenting the problem this way, $23.4 \%$ of the tested sample strongly disagree in addition to $36.7 \%$ who disagree, which means that spending money on the garden maintenance is as important as the treatments of patients.

* Most of the users believed that the hospital gardens are used as a place to provide treatment to patients $(29.4 \%$ strongly agree $+27.1 \%$ agree $)$.

* The majority of the tested sample are convinced that the hospital garden affect the psychological state of the employees and make them work better ( $40.8 \%$ strongly agree+ $36.2 \%$ agree) .

* The majority of visitors believe strongly that the hospital gardens give a soothing feeling to the visitors (52.3\% strongly agree+ $41.7 \%$ agree).

* The majority of visitors see that the green color of the garden renews hope in life for all the visitors of the garden $(45.0 \%$ strongly agree $+44.5 \%$ agree) .

* The garden users, on the other hand, disagreed that the patients are in need to good drug and good service, and not to see a beautiful garden $(29.8 \%$ strongly disagree $+28.9 \%$ disagree).

All the questions presented in the questionnaire of Table (5) have touched a main problem case which is in fact considered the main backbone of making hospital or healing gardens or not. The tested sample expressed a good level of awareness concerning the impact of hospital garden for patients and other users groups as well which is in full agreement with the findings of Cooper-Marcus and Barnes (1995) who stated, moreover, that they are convinced, after the positive results of a series of questionnaires in different places, that, with more persuasive information as to the benefits of hospital gardens, many more hospital administrators and medical staff would encourage the use of outdoor spaces as gardens for healing and stress reduction. 
Table (5):Distribution of the studied cases according to degree of satisfaction with respect to the importance of hospital gardens

\begin{tabular}{|c|c|c|c|c|c|c|c|c|c|c|c|c|c|}
\hline & \multicolumn{2}{|c|}{$\begin{array}{l}\text { Strongly } \\
\text { disagree }\end{array}$} & \multicolumn{2}{|c|}{ Disagree } & \multicolumn{2}{|c|}{ Moderate } & \multicolumn{2}{|c|}{ Agree } & \multicolumn{2}{|c|}{$\begin{array}{l}\text { Strongly } \\
\text { agree }\end{array}$} & \multirow[t]{2}{*}{ Mean } & \multirow[t]{2}{*}{ SD } & \multirow[t]{2}{*}{$\square^{\square}$} \\
\hline & No & $\%$ & No & $\%$ & No & $\%$ & No & $\%$ & No & $\%$ & & & \\
\hline $\begin{array}{l}\text { Gardens have a great psychological impact on } \\
\text { hospital's users. } \\
\text { Most Egyptians believed that the expansion of }\end{array}$ & 2 & 0.9 & 1 & 0.5 & 12 & 5.5 & 80 & 36.7 & 123 & 56.4 & 4.47 & 0.71 & $279.202^{*}$ \\
\hline $\begin{array}{l}\text { building sections of the hospital is more } \\
\text { important than the creation of green spaces }\end{array}$ & 63 & 28.9 & 60 & 27.5 & 30 & 13.8 & 48 & 22.0 & 17 & 7.8 & 2.52 & 1.32 & $35.716^{*}$ \\
\hline $\begin{array}{l}\text { Hospital gardens lead to transmission of } \\
\text { infection because of the spread of insects. }\end{array}$ & 97 & 44.5 & 89 & 40.8 & 19 & 8.7 & 8 & 3.7 & 5 & 2.3 & 1.78 & 0.92 & $189.798^{*}$ \\
\hline $\begin{array}{l}\text { Whether there is interest in gardening or not } \\
\text { does not affect the case of patients } \\
\text { Maintenance of the aarden need large sums of }\end{array}$ & 104 & 47.7 & 83 & 38.1 & 9 & 4.1 & 16 & 7.3 & 6 & 2.8 & 1.79 & 1.01 & $196.633^{*}$ \\
\hline $\begin{array}{l}\text { money so it is preferably provide these money } \\
\text { to spent on the treatment of patients }\end{array}$ & 51 & 23.4 & 80 & 36.7 & 26 & 11.9 & 37 & 17.0 & 24 & 11.0 & 2.56 & 1.31 & $48.560^{*}$ \\
\hline $\begin{array}{l}\text { Gardens used as a place to provide treatment } \\
\text { to patients }\end{array}$ & 33 & 15.1 & 36 & 16.5 & 26 & 11.9 & 59 & 27.1 & 64 & 29.4 & 3.39 & 1.44 & $25.991^{*}$ \\
\hline $\begin{array}{l}\text { The hospital garden Affect the psychological } \\
\text { state of the employees and make them work } \\
\text { better }\end{array}$ & 10 & 4.6 & 10 & 4.6 & 30 & 13.8 & 79 & 36.2 & 89 & 40.8 & 4.04 & 1.07 & $132.046^{*}$ \\
\hline $\begin{array}{l}\text { The hospital garden Feel soothing to the } \\
\text { visitors }\end{array}$ & 2 & 0.9 & 1 & 0.5 & 10 & 41.7 & 91 & 41.7 & 114 & 52.3 & 4.44 & 0.69 & $272.413^{*}$ \\
\hline $\begin{array}{l}\text { Green renews hope in life for all visitors to the } \\
\text { garden }\end{array}$ & 1 & 0.5 & 3 & 1.4 & 19 & 8.7 & 97 & 44.5 & 98 & 45.0 & 4.32 & 0.73 & $226.587^{*}$ \\
\hline $\begin{array}{l}\text { Patients in need to good drug, good service, } \\
\text { and not to see a beautiful garden }\end{array}$ & 65 & 29.8 & 63 & 28.9 & 37 & 17.0 & 32 & 14.7 & 21 & 9.6 & 2.45 & 1.31 & $34.936{ }^{*}$ \\
\hline
\end{tabular}

$\chi^{2} p$ : $p$ value for Chi-square test

*: Statistically significant at $p \leq 0.05$

\section{REFERENCES}

Annerstedt, M., and Wahrborg, P. (2011). Nature- assisted therapy: Systematic review of controlled and observational studies. Scandinavian Journal of Public Health, 39: 371-388.

Berall, J.S.(1978). The Garden: An Illustrated History Penguin Books, New York.

Brawely, E. (2007). Designing Successful Gardens and Outdoor Spaces for Individuals with Alzheimer's Disease. Journal of Housing for the Elderly 21:265-283.

Carpenter, P.L.,Walker, T.D. and Lanphear, F.O. (1975). Plants in the Landscape. W.H. Freeman and Company, San Francisco.

Carstens, D. Y. (1998). Outdoor Spaces in Housing for the Elderly. In: CooperMarcus. C. and Francis, C. eds, People Places: Design Guidelines for Urban Open Spaces, Van Nostrand Reinhold, New York. pp. 209- 251.

Cooper-Marcus, C. (2005). Healing Gardens in Hospitals. Interdisciplinary Design \& Research. E- Publication 1:1.

Cooper- Marcus, C. and Barnes, M. (1995). Gardens in Healthcare Facilities: Uses, Therapeutic Benefits and Design Recommendations. The Center for Health Design, Martinez.

Cooper- Marcus, C. and Barnes, M. (1999). Healing Gardens: Therapeutic Benefits and Design Recommendations John Wiley and Sons, Canada

Hall, D. (2008). Altar and Table: A phenomenology of the surgeon- priest Yale Journal of Biology and Medicine 81 (4). PMC 2605310 
Harris, C.W. and Dines, N.T. (1998). Time - Saver Standards for Landscape Architecture : Design and Construction Data, second edition. McGrawHill Publishing Company, Montreal, Canada.

Horsburgh, C.R. (1995). Healing by design. New England Journal of Medicine, 11 (333).: 735-740.

Janick, J. (2002). Ancient Egyptian Agriculture and the Origins of Horticulture Proc. Conf. Medit. Hort: Eds. S. Sansavini\& J. JanickActa Hort. 582 ISHS, 2002.

Jiang, S. (2014).Therapeutic landscapes and healing gardens: A review of Chinese literature in relation to the studies in western countries. Frontiers of Architectural Research, 3: 141- 153.

Kaplan, R. and Kaplan, S. (1989). The Experience of Nature: A Psychological Perspective. Cambridge University Press, UK.

Kirchner, C.E. ,Gerber, E.G., and Smith, B.C. (2008). Designed to deter : Community barriers to physically activity for people with visual or motor impairments. American Journal of Preventive Medicine, 34:349-352.

Miller, A. (2006).Jundi- Shapur, bimaristans, and the rise of academic medical centres.Journal of the Royal Society of Medicine, 99: 615-617.

Miller, C. and Lewis, D. (1999).Wayfinding :Effective Wayfinding and Signing Systems-Guidance for Healthcare Facilities. Stationery office, NHS Estates, 1999.

Minter, S. (1995). The Healing Garden: A Natural Haven for Body, Senses and Spirit. Charles E. Tuttle Company, Inc.

National Center on Accessibility (2009). Trail surfaces : what do I need to know now ? Bloomington, in : Indiana University - Bloomington. July, 2009.

Neducin, D.; Krkljes, M. and Kurtovic-Folic, N. (2010). Hospital Outdoor Spaces- Therapeutic Benefits and Design Considerations. FactaUniversitatis. Architecture and Civil Engineering, 8 (3).: 293-305.

Paine, R.; Francis, C.; Cooper- Marcus, C. and Barnes, M. (1998). Hospital Outdoor Spaces. In Francis, C.; Cooper- Marcus, C (Eds.): People Places: Design Guidelines for Urban Open Space. $2^{\text {nd }}$ edition. John Wiley \& Sons. New york.

Sagar, K.(2006). The Laughter of Foxes - A study of Ted Hughes. Liverpool University Press, Uk.

Shahrad, A.(2012).What are the design principles of healing gardens for people who are Suffering from stress-related diseases. M.Sc. Thesis, Alnarp, Swedish University of Agricultural Sciences.

Stewart, G.N. (2003). The Healing Garden: A place of peace Nyhus Stewart Publishing, Canada.

Stigdotter, U.A. and Grahn, P. (2003). Experiencing a garden- a healing garden for people suffering from burnout diseases. Journal of Therapeutic Horticulture, 14: 38-48.

Tranter, R.T., Slater, R. ; and Vaughan, N. (1991). Barriers to mobility : physically - disabled and frail elderly peoplein their local outdoor environment. International Journal of Rehabilitation Research, 14:303312.

Tyson, M.M.(1998). The Healing Landscape McGraw- Hill Books, New York. 
Ulrich, R.S. (1992). How design impacts wellness. Healthcare Forum Journal, 20: 20-25.

Ulrich, R.S. (1999). Effects of Gardens on Health Outcomes: Theory and Research, in Cooper- Marcus, C. Barness. M. (Eds.): Healing Gardens: Therapeutic Benefits and Design Considerations. John Wiley and Sons. New York: 27-86.

Ulrich, R.S.(2000). Effects of Healthcare Environmental Design on Medical Outcomes. In: Design and Health.The Therapeutic Benefits of Design. Proceedings of the $2^{\text {nd }}$. Annual International Congress on Design and Health. Karolinska Institute, stockholm.p56.

United States Access Board (1998). Americans with Disabilities Act Accessibility Guidelines. Federal Register, 63(8)::2000-2058.

United States Access Board (2007). Architectural Barriers Act ( ABA). Accessibility Guidelines for Outdoor Developed Areas; Proposed Rule. Federal Register 72 (118). : 34074-34094, Appendix A.

Wieland, G.(2007). Healthcare Exterior Design: Grounds for Healing, Medical Construction and Design Magazine, September /October 2007,pp.50-54.

York, S.L.(2009). Residential design and outdoor area accessibility. NeuroRehabilitation,25:201-208.

Young, J. (2001).SherbrookeCommunity Center :A Restorative Garden M.Sc. Thesis, University of Manitoba, Canada.

$$
\begin{aligned}
& \text { الملخص العربي } \\
& \text { تقيم بيئة حدائق مستشفى الشرطة بالاسكندرية : الإستخدام ورضا رواد الحديقة } \\
& \text { محمد جمال التركى' و ثناء مصطقى عز`ّ هند محمد امير السويفي } \\
& \text { ا ـ قسم الزهور و نباتات الزينه و تتسيق الحدائق - كليه الزراعه - جامعه الاسكندريه } \\
& \text { r. قسم الانتاج النباتى - كليه الزراعه بساباباشا - جامعه الاسكندريه } \\
& \text { ب.مهندسة لاندسكيب بمستشفى الثرطة بالاسكندرية }
\end{aligned}
$$

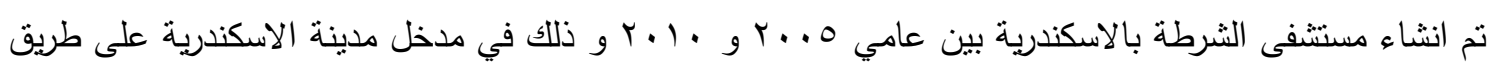

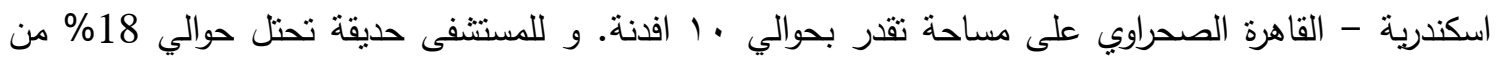
المساحة الكلية للموقع. نظرا لان فكرة حدائق المستشفيات لم تتضج بعد في مصر و العديد من دول العالم فانه نم

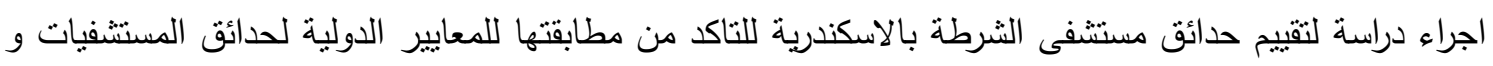

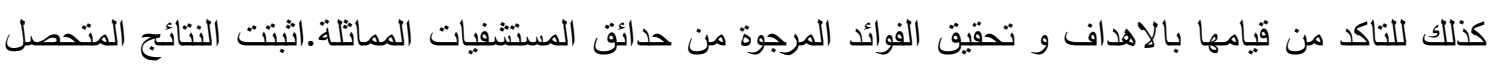
عليها من ملاحظات الموقع نفسه و كذلك من الاستبيانات ما يلي : اغلبية العينة التي تم استبيانها تعتقد ان حدائق

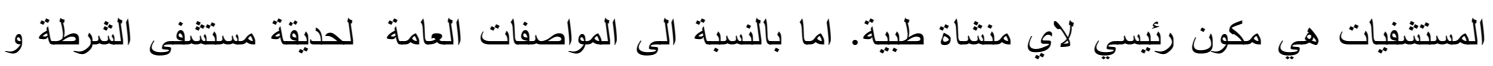

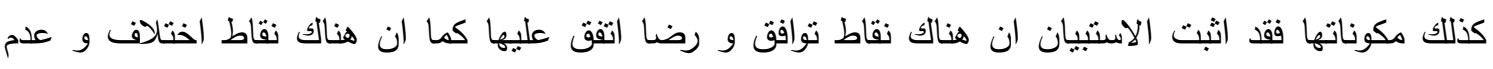

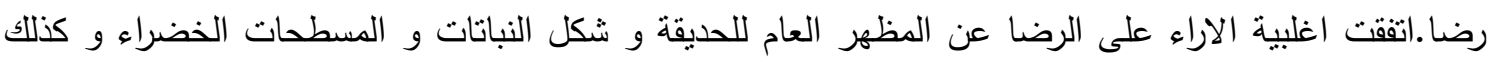
المستوى المرتفع للصيانة و النظافة العامة و الذي اعطى منظرا بهيجا للحدائق و كذللك نتج عنه مناخا صحيا 
للمرضى و لباقي زوار الحديقة.على الجانب الاخر اعترض اغلبية الافراد على عدم وجود برجولات او مظلات او

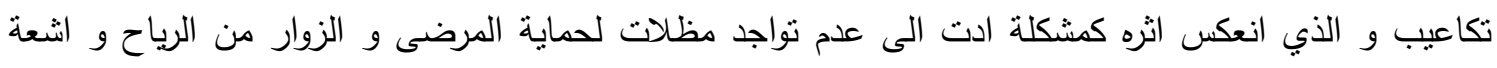

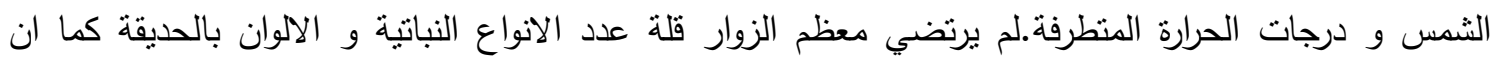

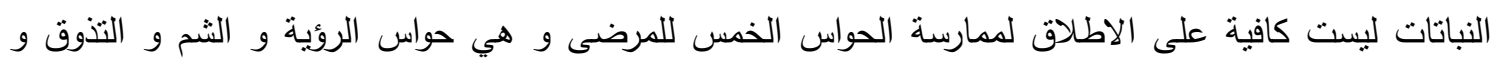

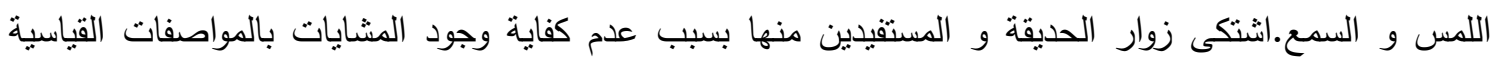
والميول التي تسمح بمرور المقاعد المتحركة للمرضى ـ كما ان غياب او عدم وجود اماكن للجلوس في الحديقة وكذلك غياب عنصر التماثيل و القطع الفنية الاخرى نم اعنباره كاحد الثكاوى الرئيسية للمرضى وزوار التئي الحديقة.

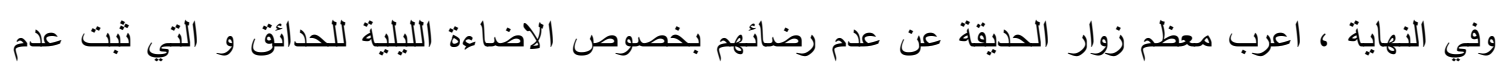
كفايتها مما يشكل مشكلة للمرضى و كبار السن و ضعاف البصر و كذللك المرضى اللذين اجتازو عمليات جراحية على عظام الساق. و بناء على تللك النتائج المتحصل عليها ، نم التوصية بتعديل الكثير من مكونات الحديقة تتجيعا لاستخدام افضل و تحقيق فوائد افضل للحديقة. و بمكن استخدام نتائج نلام الدراسة لارشاد التخطيط والتصميم والانشاء المستقبلي وكذلك تقييم بيئات الحدائق في المنشات الطبية المماثلة. 